This article was downloaded by: [Northwestern University] On: 31 January 2015, At: 09: 59

Publisher: Routledge

Informa Ltd Registered in England and Wales Registered

Number: 1072954 Registered office: Mortimer House, 37-41

Mortimer Street, London W1T 3J H, UK

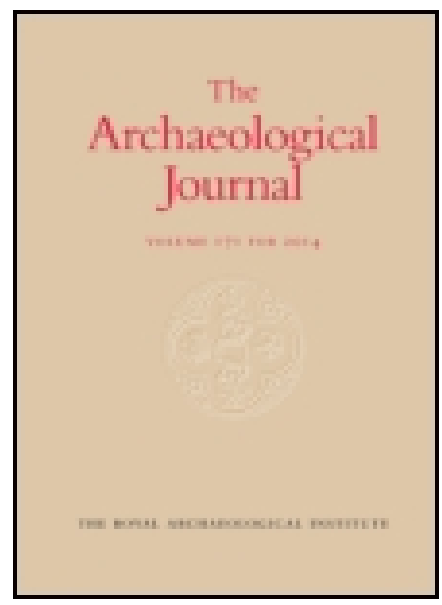

Archaeological J ournal

Publication details, including instructions for authors and subscription information: http:// www. tandfonline.com/loi/ raij20

\title{
On the Bronze Portrait Busts of Michel Angelo, Attributed to Daniele da Volterra and other Artists
}

C. Drury E. Fortnum F.S.A.

Published online: 14 J ul 2014.

To cite this article: C. Drury E. Fortnum F.S.A. (1876) On the Bronze Portrait Busts of Michel Angelo, Attributed to Daniele da Volterra and other Artists, Archaeological J ournal, 33:1, 168-182, DOI: 10.1080/00665983. 1876.10851725

To link to this article: http:// dx. doi.org/ 10.1080/ 00665983.1876.10851725

Taylor \& Francis makes every effort to ensure the accuracy of all the information (the "Content") contained in the publications on our platform. However, Taylor \& Francis, our agents, and our licensors make no representations or warranties whatsoever as to the accuracy, completeness, or suitability for any purpose of the Content. Any opinions and views expressed in this publication are the opinions and views of the authors, and are not the views of or endorsed by Taylor \& Francis. The accuracy of the Content should not be relied upon and should be independently verified 
with primary sources of information. Taylor and Francis shall not be liable for any losses, actions, claims, proceedings, demands, costs, expenses, damages, and other liabilities whatsoever or howsoever caused arising directly or indirectly in connection with, in relation to or arising out of the use of the Content.

This article may be used for research, teaching, and private study purposes. Any substantial or systematic reproduction, redistribution, reselling, loan, sub-licensing, systematic supply, or distribution in any form to anyone is expressly forbidden. Terms \& Conditions of access and use can be found at http:// www.tandfonline.com/page/terms-and-conditions 
ON THE BRONZE PORTRAIT BUSTS OF MICHEL ANGELO, ATTRIBUTED TO DANIELE DA VOLTERRA AND OTHER ARTISTS.

By C. DRURY E. FORTNUM, F.S.A.

ON the 5th of February, 1875, I had the pleasure of exhibiting to the members of this Institute, a wax medallion portrait of Michel Angelo, believed to be the original work taken from the life by his pupil Leo Leoni, and I took that opportunity of referring to other known portraits of the great Tuscan sculptor.

Those notes, together with an autotype of the wax medallion, and of Leo's medal modelled therefrom, were published in the "Arch. Journ." vol. xxxii., and I would now wish to offer a few supplementary remarks upon some of the portraits referred to in that paper, -more particularly to the bronze head, the model of which is attributed to Daniele Ricciarelli da Volterra, by Vasari, and generally believed to be by his hand.

Various works and notices, with documents from the Buonarroti archives, have since been published; moreover, a sojourn of some weeks during the last winter at Florence and elsewhere, enabled me to gather further information in respect to the bust, and to others in the same material existing in various collections, some of which have been attributed to other hands.

It will be recollected that Vasari (Vita, p. 260, ed. Lemonnier), in his Life of Angelo, after referring to the medallion portrait by Leo Leone, (Leoni or Lione, as it is variously spelt) states

"Di Michelagnolo non ci è altri ritratti che duoi di pittura; uno di mano del Bugiardino, e l'altro di Jacopo del Conte; ed uno di bronzo di tutto rilievo, fatto da Daniello Ricciarelli ; e questo del Cavalier Lione."

Now it is well known that Vasari is not always the most accurate of historians, and that implicit faith cannot be 
placed in all his records, nor in the completeness of his statements, but, in respect to the portraits referred to by him in the above passage, he doubtless would be well informed, and, had other busts of Angelo been executed by other known sculptors, in bronze or in marble, Vasari could hardly have failed to notice them ; more especially as he afterwards refers to that modelled from a plaster mask of the dead subject, taken, as it would seem, after the body had been conveyed from Rome to Florence, and sculptured in marble by Gio. Battista Lorenzi, for the Master's monument in $\mathrm{Sa}$ Croce.

But to return to the bronze busts; in my former paper I referred to

I. The bronze head fixed upon a bust of bigio morato marble, in the Capitol at Rome.

II. A similar bronze head at Oxford, fixed upon a bust made of plaster.

III. A bust, entirely of bronze, in the Casa Buonarroti at Florence, which has been ascribed to Giovanni Bologna.

IV. A bust, also entirely of bronze, and also ascribed to Giovanni Bologna, now in the Museo Nazionale at the Bargello in Florence.

V. A bronze bust, figured in the Gazette des Beaux Arts (vol. xix. p. 330).

VI. A bust (head only) in bronze belonging to M. Piot (wrongly spelt Piaud) of Paris.

Let us now see what light recent publications may have thrown upon the history and the authorship of these bronze heads and busts.

The learned Director of the Archivio at Florence, Cavaliere Gaetano Milanesi, in a notice on the portraits of Michel Angelo, forming the first of a series of short essays published on the occasion of the festival in 1875 by Sansoni of Florence, and entitled "Michelangiolo Buonarroti ; Ricordo al Popolo Italiano:" at page 14 states that

"Among the portraits in relief of bronze, one, most celebrated, is in the Gallery of the Capitol, and from its beauty is considered by some to be the same as that recorded by Vasari as the work of Ricciarelli; certainly not less beautiful is that in the National Museum of Florence. It belonged to Antonio del Francese da Castel Durante, the last servant of Michelangiolo, and, in 1570 , was sent by him as a gift to the Duke of Urbino; after his death it came with other precious objects into the possession of the Medici, through the Princess Vittoria, the last of the 
house of the Della Rovere, and wife of the Grand Duke Ferdinand II. M. Eugene Piot possesses another portrait of Michelangiolo, in the round and of bronze, said to be very fine. He maintains that it is the same that Antonio del Francese gave to the Duke of Urbino. But it appears to me difficult to believe that the portrait of the Casa Medici, into which it certainly passed by inheritance, should have been set aside and sold."

This latter remark is made in reference to M. Piot's opinion that not only is the bronze head that he possesses the identical one given by Antonio to the Duke, but that it was actually modelled by him, the son of a French joiner, who had executed constructive architectural models in wood for Michel Angelo after his designs.

The Bargello bust, together with a marble copy of the Moses, of reduced size and from the studio of Michel Angelo, also received from Antonio, had been for years in the Grand Ducal Villa the "Poggio Imperiale," whence they were brought to the National Museum, and there is every probability that it is the identical bust given by Antonio to the Duke of Urbiuo. But this bust has been attributed to Antonio del Francese, as an original portrait of his great master and executed by him. Let us also enquire further into this part of the subject.

Among the documents published by the Commendatore Aurelio Gotti in his "Vita di Michelangelo Buonarroti" (8vo. Firenze, 12th Sep. 1875) and reproduced in English translation, with the addition of valuable remarks on the master's works by Mr. Heath Wilson in his more recently published. "Life and Works of Michelangelo Buonarroti" (8vo. London, Murray, 1876), we find the following referring to these portrait busts, in letters addressed to Lionardo Buonarroti (Michel Angelo's nephew) from Diomede Leoni and Jacopo del Duca. In a letter from Diomede of 6 th Oct. 1565 , he writes ${ }^{1}$

"Gli ricordero (a Daniello) egli dice, le vostre due Teste, e troverà la mia a buon termine che gli farà venir voglia di fare rinettare le vostre, tanto piu presto;" or, as translated by Mr. Heath Wilson :2 "I remind you (Daniello) of your two busts. ${ }^{3}$ You will find mine nearly finished, which will make you wish to clean (chase) yours as soon as possible."

1 Gotti, vol. i. p. 372.

2 Op. cit., p. 56 .

3 For reasons which will appear, it had been better that this word "teste" had been translated more literally, heads. 
But Daniele was ill, had been to the baths of San Filippo, and died early in 1566, without having chased those bronze heads (if he ever intended so to do), and of which it would seem that he had cast three. As suggested by Signor Gotti, his assistants may have been less capable, and produced inferior casts of the same model ; for in a letter from Jacopo del Duca to Lionardo of the 18th April, 1566, he writes :-

"Circa le teste di mitallo, Messer Daniello gli ha gettati, ma sono in modo che hormai se hanno da fare de novo con ciselli et lime, si che non so se saranno a proposito per V. S. : fate voi. Io per me vorrei havesti il ritratto della bona memoria de missere, non d'un altro. V. S. faze lei ; commetta a qualcheduno che vi ragguaglie meglio di me. So che quel che dico, dico per amor che vi porto, et forse, essendo vivo Daniello, l'arebbe fatte condurre a un modo, che questi soi genti non so quel che faranno."

\section{As translated by Mr. Heath Wilson-}

\section{Letter of 18 th April, 1566.}

"With regard to the metal busts, Messer Daniello has cast them, but they are in such a state that they must be worked over with chisels and files, and I do not know if your Signory will like them. Do as you please. For my part I wish you had a good memorial of him and no. thing less. That which I say, I do so from regard; had Daniello been alive perhaps he would have known how to finish them, as to these people I do not know what they will do.

\section{"Dromede Leoni."}

In this translation the word "teste" is again rendered as "busts," and there is the omission of one paragraph"V.S. faze lei; commetta a qualcheduno che vi ragguaglie meglio di me;" and by a lapsus calami he has placed Diomede's instead of Jacopo del Duca's name to the letter. On the same day Michele Alberti writes:-4

"Messer Jacomo ${ }^{5}$ vostro compare mi a detto che V. S. vorebbe sapere in che termine sono le teste di bronzo de la bona memoria di Messer Michelangelo. Vi dico che sono gettate, e che se renetterano in termine di un mese o poco piu, che V. S. le potra avere. Si che V. S. stia di bona voglia, che sara servita presto e bene, Al Servizio di V. S.

"Mrchele Alberti."

This letter Mr. Wilson renders thus :-

"Rome, 17 th April, 1566.

"Messer Jacomo, your friend has informed me that your Signory

${ }^{4}$ Gotti, p. 373.

5 "Forse Jacopo del Duca." 
wishes to know in what state are the bronze busts of Michelangelo, peace be to his memory. They are cast and may be chased in a month or little more, when your Signory may have them. If you wish, you will be served faithfully and well. Ever at your service.

"Miohele Ajberti."

Another bronze portrait of Michel Angelo was, as already stated, in the hands of his servant Antonio del Francese.

Of this Antonio del Francese, as an artist, we have no record whatever, nor does his name occur as an assistant in any of the Master's or other artistic works, except in the case referred to by these letters. That he could have modelled and cast a bust portrait of Michel Angelo after that great artist's design ("designato da lui proprio"), unknown to Vasari and other of his friends, and that the bust obtained from the Poggio Imperiale, and now in the Bargello at Florence, is such a work, has seemed to me very improbable.

Antonio was Michel Angelo's maestro di casa, his servant, performing the duties of confidential attendant on his master in the place of the deceased Urbino, who was, perhaps, hardly worthy of the kindness he received during his life and the grief for his loss by his liberal and largeminded patron. That he may have been able to execute some mechanical operations of the sculptor's studio, as polishing of marble, or filing and finishing the accessories of metal work, is reasonably probable, but we have no record of him as a modeller or sculptor of even such doubtful capacity as his predecessor Urbino (Pietro Urbano), of whose bungling we have a rather severe account in a letter written by Sebastiano del Piombo to Angelo from Rome $^{6}$ on 6th September, 1521. Antonio was called del Francese, possibly, as suggested by M. Piot, as a son of one of certain French artizans, \&c., who settled at Castel Durante, of which town he was a native, and whence Michel Angelo had previously obtained other servants. How he became possessed of the small statue of the Moses does not appear, nor do we know by whose chisel it was executed. In his letter to the Duke ${ }^{7}$ Antonio fails to enlighten us on this subject, but, as also in respect of the bronze bust, he does not venture to declare them as his own

6 Gotti, Vita, vol. i. p. 141 . Heath 7 Gotti, vol. i. p. 373. Wilson, Life, p. 261. 
work, but leaves the conclusion uncertain; hence the assumption that, as stated by $\mathrm{Mr}$. Heath Wilson, "another portrait, also in bronze, was modelled by Antonio del Franzese ;" 8 and more prudently expressed by Signor Gotti in the words: "Un altro ritratto, pur di bronzo, era nelle mani di Antonio del Francese, servitore di Michelangelo, il quale lo tenera come disegnato da lui medesimo," 9 which may be, perhaps, as correctly translated : "Another portrait, also of bronze, was in the hands of Antonio del Franzese, servant of Michel Angelo, by whom he believed it was designed."

His letter to the Duke of Urbino, as published by Signor Gotti, reads thus :-

" Illmo et Eccellmo Duca, Signore e Padrone mio colendissimo.

"Ho avuto grandissima alegrezza che V. E. habbi preso sigurta d'un suo affetionatissimo vasallo come io gli sono, in servirsi del Moise di rilievo, non mio, ma dell'istessa V. E. Mi duole solo che quello non é di maggior consideratione e che non sia altro nella povera casa mia che gli sia piaciuta e degna di Vostra Eccellenza Illustrissima; perche gran gloria e consolatione mi sarebbe che tutte le mie povere facultà diventassero Moise, o cose che le gustassero ; accio io gliele potesse offerire con quel pronto animo che io dero a un mio signore e principe naturale, il quale io amo e amerò piu che me istesso et ogni tesoro del mondo. La testa della quale me fa scrivere ne l'amorevolissima sua, e il vero ritratto di Michelagnolo Bonarroti gia mio padrone, et è di bronzo designato da lui proprio, la quale io tengo qui in Roma, e ne faccio presente a V. E. e gii ho detto al suo ambasciatore che mandi per essa e procuri di mandargliela, supplicandola si degni d'accettarla volentieri, come volentieri io glie la dono, giudicando che a piu degna persona io non la potevo dedicare. Sua Excellenza si degnerà dunque accettarla da me suo humil servo e affectionatissimo vassallo e tenerla per memoria di quel valent'huomo, e se altro si trova nella mia povera casa che le gusti, supplico V. E. a pigliarle per sue, perche sue sono; e se il presente e di poca valuta, quella accetti il buon auimo del suo povero vassallo affezionatissimo. E con questa occasione gli faccio riverentia humilmente, la quale Iddio facci felice et essalti con tutta la sua illustrissima et eccellentissima casa.

"Di Roma, li 26 d'agosto 70.

"Di Vostra Excellenza illustrissima Humillissimo Servitore e vassallo Antonio del Francese."

"All' Mllustrissimo et Eccellentissimo Signor Duca d' Urbino

Signore et padrone mio colendissimo."

From these letters one may infer that the Maestro dead, and his pupil Daniele da Volterra gone also, there remained

$s$ Heath Wilson, p. 562.

9 Gotti, p. 373. 
only inferior hands, among whom some of the bronze casts made under Daniele's superintendence and from his model, were dispersed, and each, craving the patronage of Lionardo Buonarroti, wished to recommend himself as the proper person to finish these heads (maybe greatly to their injury), or to produce others which would naturally be of inferior execution. This assumption is borne out by an examination of the heads and busts that have been preserved.

From observation of such of the sixteenth century bronze portrait busts of Michel Angelo as opportunity enabled me to examine, I had formed the opinion that they were all from one and the same original model, and, during my recent sojourn on the continent, that opinion was confirmed by comparing a photograph of one with some of the others. By this comparison I found that the general arrangement of the masses of hair and beard, the lines of the lips and eyebrows, and the bend of the head precisely corresponded, and that only in trifling details of execution could any difference be observed. But the more certainly to prove what my observation suggested, I subsequently obtained the precise measurements of all, save one, which I am equally convinced is also from the same model.

These measurements were carefully taken with a pair of callipers, some by practical sculptors, some by myself, and their correspondence is remarkable. In only one respect is there a difference of any value, and that is easily explained; it is in the distance between the central lock of hair on the forehead and the fork of the beard ; the opening of this fork in the beard varies slightly in length, and it is precisely at such a point that the inequalities of casting, as then executed, into moulds formed from the same model, would be apparent, and would also be varied by the action of the chaser's tools upon such as had been more or less finished.

Of seven out of the eight busts cast, as I believe, from the one original model, and which have come under my observation, the following are-

The measurements taken by means of callipers between the following points.

A. From the point of junction of the upper and under eyelids on the outer side, to its corresponding point on the other eye. 
B. From a point on the inner lobe of one ear, to a corresponding point on the other.

C. From the lower end of a central lock of hair upon the forehead, to the junction of the fork of the beard.

D. From the same point on the central lock of hair, to the lower centre of the upper lip.

The following table will show these several measurements, in inches, on seven of the eight replicas of this bust.

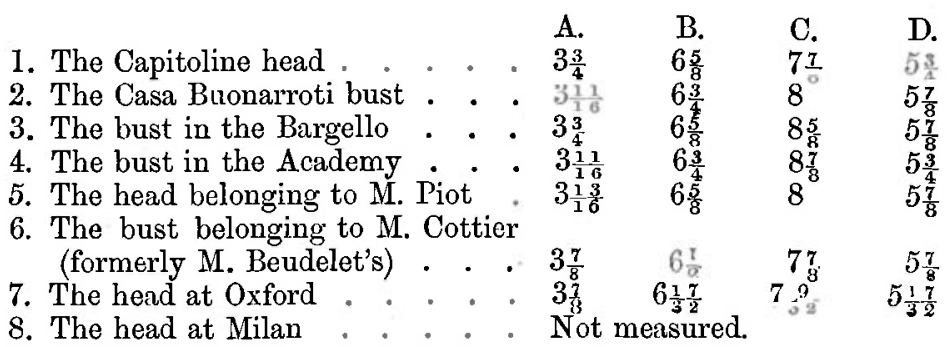

Of the head at Milan (No. 8), I was not able to procure the measurements, but it is distinctly from the same model as the others ; each and all agreeing in the pose, the arrangement of the hair, the somewhat heavy look of the eyelids, and the closed mouth. This head does not appear to have been chased or otherwise tooled after casting. These characteristics and a certain rigidity caused me to hazard the opinion that the model may have been made from a mask taken after death, and not from the living subject, but I did not then venture to express it.

Of those, the measurements of which have been given-

1. The Capitoline head is "rudely and broadly chased," to quote the observation of Mr. Warrington Wood, the eminent sculptor of Rome, who kindly, in company with $\mathrm{Mr}$. Hemans, obtained the required information for me. $\mathrm{He}$ further made the remark that it was probably modelled from a cast taken after death; thus far corroborating my previously-formed opinion.

2. The bust at the Casa Buonarroti, evidently also from the same model, shows no signs of subsequent chiselling, but, in addition to the head, the bust is also of bronze, and would seem to have been cast at the same time, as no joint is perceptible ; colouring and dust may, however, conceal it. The arrangement of the drapery on this bust differs from

Vol. XXXIII. 
that, executed in marble, on which the Capitoline head is fixed, and also from that in bronze at the Bargello.

3. The fine bust in the Bargello, all of bronze, is perhaps somewhat over-chased and tooled, the head clearly of the same model, the bust an addition thereto. This has been ascribed to Giovanni Bologna and also to Antonio del Francese. There can be little doubt that it is the bust given by the latter to the then Duke of Urbino, Francesco Maria della Rovere, from whom it was inherited by the Medici. From the Poggio Imperiale, where it had been known for years, it was brought, together with the small marble of the Moses, to the Bargello in Florence, where it now stands.

No. 4. The bust at the end of the long room of the Accadémia at Florence is a less excellent replica, also differing in the bronze drapery from that at the Bargello; it has been coarsely chased by an inferior hand.

No. 5. The head belonging to M. Piot at Paris is a very fine cast, seemingly a la cire, in its genuine state, from the carefully prepared mould, and has all the qualities of the original model without the doubtful advantage of chasing by a less artistic hand. It was purchased by him from a private possessor at Bologna, several years since, in whose hands I had previously seen it, and regret, too late, having neglected to secure it for my own collection. As I have already stated, M. Piot considers it to be that given by Antonio del Francese to the Duke of Urbino, and also that it was his work. M. Piot ascribes that in the Bargello to Giovanni Bologna. In these opinions I cannot agree.

6. The bust belonging to M. Cottier of Paris, who purchased it from M. Beudelet, is a less successful cast. The head is upon a half bust of smaller size and differing in drapery from the others; it represents the upper portion of a tunic buttoned closely to the collar. It may have been slightly refreshed by the file, etc., but not by an artistic hand.

7. The head at Oxford is mounted on a draped bust made of plaster. There can be little doubt of the correctness of Mr. Robinson's statement," that "the present is a fine wax casting, and doubtless the work of a great sculptor. It represents Michel Angelo in his extreme old age, and it

I "The Drawings by Michel Angelo and Raffaello, \&c.," 8vo. Oxford, 1876. P. 101, No. 90 . 
seems to have been modelled from nature." This head was presented to the University of Oxford by the late $\mathrm{Mr}$. W. Woodburn.

In a conversation with Professor Emilio Santarelli, a sculptor well known to fame, and whose knowledge, arising from long and loving study of the works of the great renaissance artists, is perhaps unrivalled in Florence, without any suggestion on my part, also expressed the opinion that the original model of these busts had been worked from a mask taken after death, again corroborating Mr. Wood's and my own opinion.

From the foregoing data we find that of the eight known replicas-

3 (Piot, Oxford, Milan) are heads only, and not chased.

1 head (the Capitoline) "rudely and broadly chased."

1 bust (the Buonarroti) not chased.

3 busts (Bargello, Academy, Cottier) more or less chased.

Gaetano Milanese, in his paper before referred to, states that according to the domestic archives of the Buonarroti family Ricciarelli cast three heads, two for Lionardo Buonarroti and one for himself.

Referring to the letter of 17 April, 1566, from Michele Alberti, we may infer that Alberti had other of the busts, we know not how many, under his charge, seemingly for the casting as well as for completion; for he cannot refer to that one already chased by Diomede Leoni, nor can it be inferred, from the wording of his letter, that he alludes to the two left by Daniele (perhaps purposely) as they came from the mould.

Again, we know that one (that now at the Bargello) was in the hands of Michel Angelo's servant, Antonio del Francese, who, very possibly, may have been a metal chaser, although we have no evidence of his artistic capacity. Six or seven at least are therefore accounted for, and the indefinite statement as to number in Alberti's letter, leaves a margin for some more. It is, moreover, not unreasonable to suppose that two or three may have been cast from Daniele's model immediately after his death, and that these, although in every other respect similiar, would want the sharpness and perfection of the earlier casts made under the modeller's own eye. 
The conclusions to be drawn from the foregoing facts would therefore seem to me-

1. That all these eight bronze and authentic portrait busts of Michel Angelo are replicas from one and the same model.

2. That that model was the one alluded to by Vasari as the work "di tutto rilievo" of Daniele Ricciarelli da Volterra, and that in all probability it was executed by him from a mask taken immediately after death, rather than from the living model.

3. That none of these bronze busts (and no others of that period are known) were modelled by Diomede Leoni, Antonio del Francese, nor Michele Alberti.

4. That some were left in the state in which they came from the mould. (Piot, Oxford, Milan.)

5 . That others were more or less chased by more or less competent hands.

6. That two at least, having the drapery, \&c., also cast in bronze (as the Academy and the Cottier, and perhaps the Casa Buonarroti) were probably cast after Daniele's death, tut from his model of the head.

Of the heads originally cast by Daniele da Volterra, and perhaps intentionally left unchased by him, I should consider from its excellence that that belonging to M. Piot is one, and that at Oxford may be the other. That at Milan does not seem to have been worked over, but the Capitoline head would appear to have been chased.

The Bargello bust has been elaborately tooled, even to harshness, and, if capable of such mechanical work, may have been chased by the hand of Antonio del Francese, to whom it belonged. We have, however, no account of the subsequent history of that head of which Diomede Leoni states in his letter that "you will find mine nearly finished." As one of a family of medallists and metal workers, it would seem more reasonable to suppose that the highly-fimished bust at the Bargello (which by the way has had casts taken from it recently, and has been cleaned, much to its disadvantage), is that which was finished by Leoni, and may have been subsequently left in Antonio's hands. It is also possible that Leoni would not venture to chase so highly, and that the Capitoline head, which has perhaps an earlier look about it, may have been that to which he alludes. 
A letter also is printed by Signor Gotti (vol. i. p. 373), from Jacopo del Duca to Leonardo, in which he speaks of the heads cast by Daniele as being very rough, and wanting the action of chisel and file; that had Daniele lived he might have finished them, but of "soi genti," he knew not what they could do. He expresses a wish that Leonardo should have a worthy memorial of the master, and hints (in a passage omitted from the translation of the letter by Mr. Heath Wilson') that he would serve him if there be no other whom he regards with higher favour. Possibly, therefore, one of the heads or busts may have been cast from the original model, or finished up by or under the direction of Jacopo del Duca. These, however, are conjectures of but little weight; the facts I have been able to adduce are more important.

I would correct one other suggestion in my former paper. None of these bronze busts could have been cast from Giovanni Battista Lorenzi's marble on the monument in Sta. Croce. It was modelled from a mask taken after death, as Vasari tells us, but differs materially from those of bronze, the head being turned in the opposite direction, viz., to its own left.

I would also take this opportunity of correcting some and adding other matter to that in my former paper, in respect to other portraits of the great Maestro.

Of the monument near the sacristy of the SS. Apostoli at Rome, much has been written; but the documents since published by Signor Gotti ${ }^{3}$ would seem to prove that it was erected in honour of the great sculptor's memory, and not, as I was led to conclude, to that of Filippo or Ferdinando, Eustachio da Macerata. These documents consist of letters from Jacopo del Duca, Diomede Leoni, and Daniele da Volterra, written in Rome, and from Leonardo Buonarroti in Florence; they, however, refer only to the epitaph, and give us no distinct information as to the artist who executed that bas-relief.

In reference to the medal by Leo Leoni, there is an interesting letter from that artist addressed to Michel Angelo from Milan on the 14th March, 1561, in which he states that he has sent by the hands of Carlo Visconte four of

2 "V.S. faze lei; cometta a qualckeduno che vi ragguaglie meglio di me."

3 Vita, vol. i. p. 369 , et seq. Heath Wilson. Op. oit. 
these medals, two of silver and two of bronze. He begs him to keep that one which is in a case, and is more highly finished, and to do with the others what he pleases. His letter reads thus :-

"Molto magnifico signor mio, sempre osservandissimo.

"Mando a V. S. per lo signor Carlo Visconte, grande huomo in questa cita di Milano, et amato da Sua Santita, quatro medaglie de la vostra efiggie: le due sarano d'argento et l'altre due di bronzo. Sarei stato piu breve a mandarle a V. S. se non fussi cosi occupato ne l'opera che per cagione di V. S. ebbi da Sua Santita (la sepoltura della quale è parlato sopra), et se anchora non avessi fede che V. S. mi perdonasse l'errore de la tardanza, ma non già il peccato de l'ingratitudine.

"Quella che è nel bossolo è tutta rinettata et la guardera e conservara per amor mio. L'altre tre ne farà ciò che gli parera; percioche, sendo ch'io per ambitione ne ho mandate in Spagna et in Fiandra, così per amore ne terò mandate a Roma et in altre parte. Dissi ambitione, per ciò che mi par haver troppo aquistato ad haver guadagnato la gratia di V. S. ch'io estimo molto : et chi non si terebbe da molto, poiche in meno di tre mesi ho due lettere scritemi da voi huomo divino, non come a servitor di cuore e di volontà, ma da figliuolo? Horsù io non darò piu fastidio per hora a V.S., ecetto che la prego che mi voglia perseverare d'amarmi, et dove occore, favorirmi, e al signor Tomao del Cavallieri dir ch'io non saro smemorato. Il Signore vi dia ogni contento accio io habbia contento.

"Da Milano, il xiiij de marzo del 61.

"Di V. S. servitor obligato "II cavalier Leone."

I have before referred to an example of this medal in silver, now in the South Kensington Museum. Another is in the cabinet of the Uffizi at Florence. Whether more were made in that material we do not know.

I would here also wish to record the opinion of the Cavaliere Gaetano Milanese, on the inscription placed at the back of the wax medallion portrait of Michael Angelo by Leo Leoni, described and figured in my former paper. Signor Milanese considers that the lettering, executed in printing character, is not of so early a date as the sixteenth century; but, on the other hand, that the composition and wording may well be of that period. He thinks, therefore, that this inscription may probably have been copied verbatim from Leoni's original memorandum, in more convenient form for insertion in the frame.

I would also take this opportunity of adding a few notes to my former paper in reference to painted and other por- 
traits of M. Angelo. Of those executed by the brush, that (Arch. Journal, vol. xxxii. p. 12, n. iii.) ascribed to Marcello Venusti, and now hanging in the Casa Buonarroti, is hard and dry in treatment, but has the appearance of originality. Not improbably this may have been taken from the life, and copied in Venusti's reduction of the Last Judgment (No. II.) now at Naples. There can be little doubt that the portrait in the Capitoline Gallery at Rome (No. 5 of my list) is a replica or a copy of the Casa Buonarroti portrait, and perhaps also by the hand of Venusti. The head almost exactly agrees, but with the addition in the Roman picture of a draped bust.

Of the much injured and unpleasing portrait in the Gallery of the Uffizi (No. 4) there is a replica in superior condition now in the possession of the Avocato Casaglia at Florence. One of these may be the original by Bugiardini referred to by Vasari, and the peculiar prominent effect given to one eye would seem to warrant Angelo's criticism (p. 13), as stated by that biographer.

The portrait by Jacopo del Conte is believed by Signor Milanese to be in the possession of the Strozzi at Florence, for whom he thinks it was painted, and he refers to the engraving in the "Serie degli Uomini illustri" - the work in folio, Firenze, 1776, vol. 4-in which it is stated that it was executed from the original, belonging to the Prince Ferdinando Strozzi.

Of the portrait by Francesco Salviati, engraved in the quarto work, "Serie, \&c." (No. 6 of my list), in which it is stated that the original belonged to the Bracci family, Signor Milanese believes it to be that now belonging to M. Chaix d'Estang.

He also refers to a fine portrait in which Angelo is represented wearing a hat, and as of about 55 years of age. This belongs to the Marchese Lotteringo della Stufa, of Florence, but can hardly be that painted by Bugiardini, as has been suggested.

Another portrait that belonged to Signor Fedi has also been attributed to Bugiardini by Signor Zobi in his brochure, ${ }^{4}$ and confounded with the Casa Bracci portrait.

A painted portrait, attributed by its possessor and some

${ }^{4}$ On the subject of these portraits refer to a short article by Gaetano Milanese, before referred to. 
others to Michel Angelo's own hand, belongs to Signor V. de Tivoli, of Oxford. It represents him as somewhat passed middle age.

I should also mention here that in a picture in the third chapel to the left, the Montaguti, on entering the church of the Annunziata at Florence, and representing a scene of the Last Judgment, from a portion of M. Angelo's great work, Alessandro Allori has introduced a portrait of that master.

To the engraved portraits of Michel Angelo referred to I would also add one representing him in a fur cap, and varied from that numbered $V$ in my list at page 14 of my former paper: The plain oval surrounding border bears the same inscription, but in larger lettering, and is without the letters I. B. and the ornamental cartouche; his age, moreover, is stated as lxxiii.

A copy of this rare variety is in M. Piot's possession. M. Piot also possesses the original letter from Diomede Leoni to Leonardo Buonarroti, in which he states that Daniele da Volterra had gone to the baths of San Filippo, near Siena, and that the two busts were nearly finished.

Among the original drawings preserved in the Florentine gallery is one in pen and ink attributed to Giorgio Vasari, a portrait of his friend Michel Angelo. This has been engraved as a frontispiece to Mr. Heath Wilson's highly interesting "Life and Works" of the great Maestro, with the addition of an architectural framing.

At Weimar, in the Grand Ducal Collection, is a fine pen drawing, a portrait of Michel Angelo, the work of $B$. Passarotti. 